\title{
Legal Study on Implementation of Individual Limited Company Post Application of The Copyright Law
}

\author{
O.K. Isnainul ${ }^{1}$, Jose Armando Parlindungan Marbun ${ }^{2}$, Yusriando ${ }^{3}$ \\ \{okisnainul@unprimdn.ac.id ${ }^{1}$, josearmando14296@yahoo.com ${ }^{2}$ \} \\ Universitas Prima Indonesia
}

\begin{abstract}
Individual Limited Companies and ordinary LCs based on Law No. 40 of 2007 concerning Limited Companies and Law No. 11 of 2020 concerning job creation. To analyze the advantages and disadvantages of individual LC and ordinary LC according to Law No. 40 of 2007 and the Copyright Act. To analyze the implementation of LC in the work copyright law. The results of the research are the difference between limited companies regulated in Law No. 40 of 2007 concerning LC and the work copyright law, there is a new thing, namely Micro and Small companies which are regulated in article 153 that is divided into 10 Articles (153A, up to $153 \mathrm{~J}$ ). The advantages of LC are the separation between the assets of the founders of the LC, ownership of capital in the form of shares that are easy to transfer to other parties, the establishment of LC with an unlimited period. As for the disadvantages of an LC namely that the dissolution of an LC must be approved by the GMS. The confidentiality of the company is not guaranteed, the capital to establish it is quite large. The implementation of the latest procedures and conditions for the establishment of an LC in 2021 is made it easier to improve the investment ecosystem, convenience, protection, and empowerment of MSMEs as well as ease of doing business in general. The procedures and conditions for establishing a Limited Company have been carried out again, and this time the umbrella is the Job Creation Law. In this regulation, there are several changes related to the procedures and conditions for the establishment of an individual company. Where to establish an LC, it is no longer necessary to go to a Notary. It is enough only to make a statement of establishment and ratify it to the Minister of Law and Human Rights.
\end{abstract}

Keywords: Legal Studies, Implementation, Limited Company

\section{Introduction}

The government has carried out various innovations in the fields of science and technology and the economy to compete in the national and international world. In the field of regulation concerning the ease of doing business for the economy, various arrangements are created to encourage, mobilize and control various development and economic activities. Renewal of legal regulations needed to support economic movement is LC [1]. LC is established by people who have the same purpose of doing business in LC is chosen as the person's business entity which is establish through an agreement outlined in the agreement, for the validity of an agreement according to the provisions contained in Article 1320 of the Civil Code [1]. In Indonesia, there are several types of business fields, and one of these business fields is LC, and in recent years it has been in great demand, and its liability is limited. LC 
shareholders are given the convenience to transfer the company to any community that wants to sell their ownership shares with the benefits of the LC [2]

There is also a Limited Liability Company regarding the legal rules contained in Law No. 40 of 2007 as a legal entity consisting of a combination of capital which, established based on an agreement, between the founders to run a business with the authorized capital divided into shares in the LC that is stipulated under the Limited Company Law and its implementing regulations [3] According to the current government, to encourage economic growth in Indonesia, it must accelerate the increase in investment, one of which is in the investment sector. Changes were made to avoid various investment obstacles, namely by eliminating overlapping regulations. Therefore, it is necessary to facilitate business licensing and investment in MSME workers in land management as well as provisions regarding government administration requirements and the imposition of criminal law on various laws [4].

MSME actors choose individual businesses or limited companies in running their business. MSME actors do not select a business entity in the form of a LC legal entity even though the LC has the characteristics of limited liability where the shareholders are only responsible for the paid-in capital. However, the biggest obstacle for MSME actors to establish a LC legal entity is the capital factor and the business partner factor. Based on Law No. 40 of 2007 concerning Limited Liability Companies, the minimum authorized capital of a LC is fifty million Rupiah. The rule with PP number 29/2016 has changed the minimum authorized capital, from a minimum of fifty million Rupiah to no minimum limit on the value of authorized government. It is the Government's effort to support MSME actors to do business through the legal entity LC. The government promulgated Law No. 11 of 2020 concerning Job Creation.

One of the changes with the enactment of the Job Creation Law is the amendment to Law Number 40 of 2007 concerning LC. The amendment to Law No. 40 of 2007 concerning Limited Companies is a significant change because the Job Creation Law introduces a completely new concept, namely Individual Legal Entities in the Form of LC. The Employment Copyright Act regarding the amendment to Law Number 40 of 2007 concerning LC is once again the government's effort to encourage MSEs to do business through the Legal Entity LC. The concept of an Individual Legal Entity in the form of a Limited Company is a new thing and certainly needs to be studied more comprehensively regarding its regulation and implementation, so the authors are interested in bringing up the title: Legal Studies on the Implementation of Individual LCs after the Enforcement of the Job Creation Law. By discussing the problems in this research:

1. How is the difference between an individual limited company and an ordinary limited company based on Law No. 40 of 2007 with the copyright law?

2. What are the advantages and disadvantages of an individual limited company and an ordinary limited company according to Law No. 40 of 2007 and the work copyright law?

3. How is the implementation of LC in the work copyright law?

\section{Research Methods}

Research method as the science of research, teaches theoretically about general principles, while the method as a scientific way of working in research carried out starts from determining the nature and character of research, formulating problems as the core object of 
research, formulating hypotheses (if needed), thematic or research title, theoretical research framework, research methods, discussion of research results, conclusions and suggestions, and other research instruments [5].

Research methods (research methods) as a way of scientific work in conducting research activities, following the nature and character of scientific objects, for example, natural sciences (nature), having their scientific character following the nature of the scientific character in the genus, and species character of the field their respective specialist studies [6] The type of research used is normative legal research by reviewing literature in the form of books and other documents, such as laws, court decisions, and legal doctrines [7].This research is descriptive research is research by describing the state of nature and conditions created by humans. Like various phenomena that are happening in various communities, then an analysis is carried out and concludes these phenomena [8].

The sources of legal materials used in this research are Primary Legal Materials, Secondary Legal Materials, and Tertiary Legal Materials. With the data collection techniques used. To obtain appropriate data and those studied in this study, legal materials were collected through library studies and observations, namely by collecting data through learning books, documents, and literature related to this research.

\section{Results and Discussion}

\subsection{Advantages and Disadvantages of Limited Companies and Sole Proprietorships}

1. The advantages that will be obtained by business actors in choosing a Limited Company as a forum for doing business are as follows: [9]

Table 1

\begin{tabular}{|c|}
\hline ADVANTAGES \\
\hline $\begin{array}{l}\text { a. Personal Assets and Assets are Safer } \\
\text { According to Article } 3 \text { paragraph (1) of Law no. } \\
40 \text { of } 2007 \text { concerning LC }\end{array}$ \\
\hline $\begin{array}{l}\text { b. Shareholding } \\
\text { Easily Transferable When choosing to establish } \\
\text { a PT, the capital entered will be divided into } \\
\text { shares, as stated in Article } 31 \text { paragraph (1) of } \\
\text { Law No. } 40 \text { of } 2007 \text { concerning Limited } \\
\text { Liability Companies. }\end{array}$ \\
\hline $\begin{array}{l}\text { c. Unlimited Term } \\
\text { By choosing a LC as a business entity, the term } \\
\text { of the company can be unlimited. According to } \\
\text { Article } 6 \text { of Law No. } 40 \text { of } 2007 \text { concerning LC. }\end{array}$ \\
\hline $\begin{array}{l}\text { d. Easier to Get Funding } \\
\text { In the business world, there are times when you } \\
\text { need additional capital to develop from the } \\
\text { business activity itself. By having a business } \\
\text { entity as a legal entity, especially in the form of } \\
\text { an LC, it is easier to get capital in the business } \\
\text { world from the Bank. }\end{array}$ \\
\hline
\end{tabular}

\section{DISADVANTAGES}

a. First, many people think that the procedure for establishing a Limited Company is relatively more difficult because many business licenses need to be taken care of after a Limited Liability Company is established through a Notary.

b. Second, the process of dissolving an LC is not as easy as dissolving another business entity. Due to its status as a legal entity and considered as an entity. Its dissolution is also specifically regulated in Law No. 40 of 2007 concerning LC. 
2. The advantages and disadvantages of individual Limited Company

Table 2.

\begin{tabular}{|c|}
\hline Advantages Individual LC \\
\hline 1. Ease of Establishment \\
\hline $\begin{array}{l}\text { 2. The cost to establish an individual company is } \\
\text { cheaper than a limited liability company in general } \\
\text { because to establish an individual company. It is } \\
\text { enough only to make a statement of the } \\
\text { establishment. It is not required to make a deed of } \\
\text { the establishment before a notary as the } \\
\text { establishment of a limited liability company is } \\
\text { generally contained in Law Number } 40 \text { of } 2007 \\
\text { regarding LC. }\end{array}$ \\
\hline $\begin{array}{l}\text { 3. The authorized capital for establishing an } \\
\text { individual company is not determined as contained } \\
\text { in PP No. } 8 \text { of } 2021 \text {. }\end{array}$ \\
\hline
\end{tabular}

\begin{tabular}{l} 
Disadvantages Indovidual LC \\
\hline \begin{tabular}{l} 
1. If the shareholder is more than 1 (one) \\
person, then the individual company is obliged \\
to change its legal entity status to become a \\
limited liability company \\
\hline 2. An individual company can only be \\
established for business activities that meet \\
the MSE criteria, excluding land and buildings \\
for business premises. \\
\hline 3. In individual companies there are no LC \\
Organs in general, namely the GMS, the \\
Board of Commissioners and the Board of \\
Directors
\end{tabular} \\
\hline
\end{tabular}

3.2 The Implementation of Individual Limited Company in the Job Creation Act

Implementation in the KBBI defines as the implementation or application. Meanwhile, according to Fullan that implementation is an idea or thought about a program to achieve a change for the community. Implementation, according to Muhammad Joko Susila stated that implementation is an idea or thought to make a change in skills and attitudes. The ease of procedures and conditions for establishing a Limited Company continues to be held, and the legal umbrella is the Job Creation Law. Through this regulation, there are changes related to the procedures and requirements that must be met to ratify the latest LC.

\subsubsection{Establishment of LC for MSEs}

LC is a legal entity that has a capital partnership. It is established based on an agreement, carries out a business activity with authorized capital that is entirely divided into shares or individual legal entities that meet the MSE criteria as stipulated in the laws and regulations regarding the MSE. Then, the obligation of LC established by at least two people also changes, with increasing types of LC that can avoid this. The establishment of an LC can be done alone without having to join with other parties as long as the provisions of the business carried out meet the type of MSE. This, in contrast to LC, the process of establishing an LC for MSE does not require a deed of establishment; it is enough with a statement of establishment in Indonesian.

\subsubsection{The way to Get LC Legal Entity Status}

With a statement of establishment containing the articles of association and other information regarding $\mathrm{LC}$, it is a requirement for the establishment of a LC with the type of 
MSE. Having a deed of establishment does not mean that the LC has obtained the status of a legal entity. Before the ratification of the Job Creation Law, the LC obtained the status of a legal entity on the issuance date of the Decree of the Minister of Law and Human Rights concerning the legalization of the legal entity LC. After the existence of the Job Creation Law, LC obtains the status of a legal entity after being registered with the Menkumham and obtaining proof of registration.

a. Minimum Amount of Authorized Capital LC

The Company Law requires the amount of authorized capital to establish a Limited Company at a minimum of fifty million rupiahs. Things are different after the enactment of the Job Creation Law, to improve the ease of doing business, simplify the requirements for the establishment of an LC by eliminating the minimum amount of authorized capital and replacing it with the amount of authorized capital of an LC determined by the decision of the founder of the company. The simpler the establishment capital of an LC makes it easier for investors regarding the minimum limit of authorized capital when creating an LC.

b. Revoke Law No. 3 of 1982 concerning Compulsory Company Registration

Law No. 3 of 1982 requires companies that are domiciled and run a business to be registered in the Company Register. One form of company that must be registered is LC.

c. Application of Risk-Based Business Licensing

The Job Creation Law changes the rules regarding business licensing. With the provisions, the application of licensing is held with the provisions of determining the level of risk and rating the business scale of business activities. Determined by the level of risk and the business scale rating of activities with for categories which will be explained in the table below:

\section{Conclusion}

The advantage of a Limited Company is a separation between the assets of the founder and limited company ownership of capital in the form of shares that are easy to transfer to other parties, the establishment of a limited liability company with an indefinite period, easier to obtain funding from investors, opening up broad business opportunities, mandatory under applicable law, and increasing credibility. The disadvantages of a Limited Company are the dissolution of a limited company must be approved by the General Meeting of Shareholders, the confidentiality of the company is not guaranteed, the amount of tax that must be paid is quite large, the capital to establish it is large enough, the survival of the company depends on the shareholders, and ownership from the company is easy to change hands. As for the implementation of the latest procedures and conditions for the establishment of Limited Liability Companies in 2021, it is easier to improve the investment ecosystem; convenience, protection, and empowerment of MSMEs; and ease of doing business in general.

The simplification of the procedures and conditions for the establishment of LC was again carried out, and this time the umbrella was Law Number 11 of 2020 concerning Job Creation. Through this rule, there are several changes related to the procedures and conditions for the establishment of an individual company. Where to establish a limited company, it is no longer necessary to go to a Notary. It is enough to only make a statement of establishment and ratify it to the Minister of Law and Human Rights. 


\section{References}

[1] Andrea, F. 2007. diterjemahkan oleh Adiwinata A. Teloeki dan H. Boerchanudin St.Batoeh, 2007, Kamus Istilah Hukum,Cet.Pertama, Jakarta, Binacipta 2007.

[2] Atmosudirdjo,P. 1995. Hukum Administrasi Negara, Ghalia Indonesia, Jakarta

[3] Chidir,A. 2007. Badan Hukum. Bandung: Alumni.

[4] Fajar, M., and Achmad, Y. 2010. Dualisme Penelitian Hukum Normatif dan Empiris. Pustaka Pelajar, Jakarta

[5] Ginting, J. 2007. Hukum Perseroan Terbatas (UU 40 Tahun 2007), PT. Citra Aditya Bakti, Bandung

[6] Harahap, M.,Y. 2011. Hukum Perseroan Terbatas. Sinar Grafika, Jakarta

[7] H.D. van Wiljk Willem Konijnenbelt. 1988. Hoofdstukken van Administratief Recht, Uitgeverij LEMMA BV, Culemborg

[8] Ibrahim, J. 2008. Teori dan Metodologi Penelitian Hukum Normatif. cet IV, Bayu Media Publishing, Jawa Timur

[9] Marbun, S., F. 2004. Mandat, Delegasi, Atribusi Dan Implementasinya Di Indonesia,UII Press, Yogyakarta

[10] Mulhadi. 2010. Hukum Perusahaan (Bentuk-Bentuk Badan Usaha Di Indonesia). Ghalia Indonesia, Bogor

[11] Nadapdap, B. 2020. Hukum Perseroan Terbatas Berdasarkan Undang-Undang Nomor 40 Tahun 2007 Tentang Perseroan Terbatas. Jala Permata, Jakarta

[12] Sayuti, H. 1989. Pengantar Metodologi Riset. CV Fajar Agung, Jakarta

[13] Soekanto, S. 1986. Pengantar Penelitian Hukum, Jakarta, Universitas Indonesia

[14] Siswosoediro, H.S. 2008. Buku Pintar Pengurusan Peizinan \& Dokumen, Visimedia: Jakarta

[15] Waluyo, B. 1996. Penelitian Hukum Dalam Praktik. Sinar Grafika, Jakarta

[16] Yani, A., and Widjaja, G. 2003. Perseroan Terbatas. Jakarta: PT. Raja Grafindo Persada 